\title{
Reflective perspectives on Paul
}

\begin{tabular}{|c|c|}
\hline \multicolumn{2}{|c|}{ Author: } \\
\hline \multicolumn{2}{|c|}{ 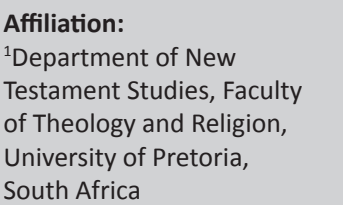 } \\
\hline \multicolumn{2}{|c|}{$\begin{array}{l}\text { Research Project Details: } \\
\text { Project Leader: A.G. van Aarde } \\
\text { Project Number: } 2334682\end{array}$} \\
\hline \multicolumn{2}{|c|}{$\begin{array}{l}\text { Project Description: } \\
\text { This research is part of the } \\
\text { research project, 'Biblical } \\
\text { Theology and Hermeneutics', } \\
\text { directed by Prof. Dr Andries } \\
\text { van Aarde, Post Retirement } \\
\text { Professor and Senior } \\
\text { Research Fellow in the Dean's } \\
\text { Office, Faculty of Theology } \\
\text { and Religion, University of } \\
\text { Pretoria. }\end{array}$} \\
\hline \multicolumn{2}{|c|}{$\begin{array}{l}\text { Corresponding author: } \\
\text { Andries van Aarde, } \\
\text { andries.vanaarde@aosis.co.za }\end{array}$} \\
\hline \multicolumn{2}{|c|}{$\begin{array}{l}\text { Received: } 30 \text { Aug. } 2018 \\
\text { Accepted: } 07 \text { Sept. } 2018 \\
\text { Published: } 31 \text { Oct. } 2018\end{array}$} \\
\hline \multicolumn{2}{|c|}{$\begin{array}{l}\text { How to cite this article: } \\
\text { Van Aarde, A., 2018, } \\
\text { 'Reflective perspectives on } \\
\text { Paul', HTS Teologiese Studie } \\
\text { Theological Studies } 74(4) \text {, } \\
\text { a5248. https://doi.org/ } \\
\text { 10.4102/hts.v74i4.5248 }\end{array}$} \\
\hline \multicolumn{2}{|c|}{$\begin{array}{l}\text { Copyright: } \\
\text { (c) 2018. The Authors } \\
\text { Licensee: AOSIS. This } \\
\text { is licensed under the } \\
\text { Creative Commons } \\
\text { Attribution License. }\end{array}$} \\
\hline \multicolumn{2}{|l|}{ Read online: } \\
\hline 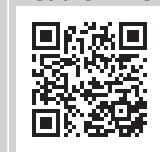 & $\begin{array}{l}\text { Scan this QR } \\
\text { code with your } \\
\text { smart phone or } \\
\text { mobile device } \\
\text { to read online. }\end{array}$ \\
\hline
\end{tabular}

The article explores various aspects of understanding Paul. It focuses on his use of the expression 'the gospel of God' as the 'good news' that originates with God (a subjective genitive) and one that is about God (an objective genitive). The article argues that the cross and resurrection constitute the core of Paul's message and that this message demands a new ethos because of the 'dying and rising' in participation with Christ Jesus. For Paul, the messianic era had already commenced. In Paul's point of view, the heart of the gospel was the announcement of a historical happening, namely the crucifixion of the historical Jesus which is connected to another 'event', namely the resurrection of Jesus, which does not qualify as history. For Paul, faith is engagement with the kerygma, and not a kind of loyalty to inherited religious customs. Faith implies undivided loyalty, a personal decision and commitment to believe what is proclaimed.

\section{Prolegomena}

The aim of this article does not consist of a formulation of a hypothesis about an identified gap in existing Pauline studies - which I am convinced that, currently, it ought to be the substantiation of one of its present-day trends, namely that Paul's theological dispositions should be considered to be intrinsically political in nature (cf. inter alia Agamben 2005; Blumenfeld 2001; Breytenbach 1989:40-83; Constantineanu 2006; Elliott 2005; Ward 2012:476). Such an argumentation is vital and I will address it elsewhere. However, the goal of this article is rather to highlight the fundamental building blocks of my reading of Paul - a basis that is a necessity for explaining my theological dispositions that will be attended in my forthcoming two-volume collected works to be published by Cambridge Scholars Publications in 2019, titled Jesus. Paul. Matthew, Volume One: Discontinuity in Content, Continuity in Substance and Jesus. Paul. Matthew, Volume Two: To and From Jerusalem. This essay consists therefore of the presenting of excerpts from my reflective perspectives on the primary texts of the pioneer in formative Christianity, namely the apostle Paul. In the aforementioned two volumes, an elaboration on these perspectives in a coherent way constitutes the fourth section of Volume One, under the heading 'The Gospel of Paul'.

\section{The 'truth' of the gospel according to Paul}

Paul describes his message as 'gospel' but designates himself 'apostle' rather than 'evangelist'. When Paul uses the expression 'the gospel of God' (1 Th 2:2, 8, 9; 2 Cor 11:7; Rm 1:1; 15:16) his intention is to refer to the 'good news' that originates with God (a subjective genitive) and one that is about God (an objective genitive) (Keck [1979] 1988:35). The same applies to the expression 'the gospel of Christ' (1 Th 3:2; 1 Cor 9:12; 2 Cor 2:12; 9:13; 10:14; Gl 1:7; Phlp 1:27; Rm 15:19; cf. Rm 1:9). Dunn (1998:166) points out that the theological implication of the ambivalence in this grammatical construction is that the 'gospel of Christ vindicates the faithfulness of God' (Dunn's emphasis). The radicality of the gospel's power is that it has the capacity to bring about change in

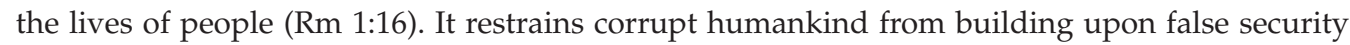
based on unenduring elements of creation. Paul refers to this power as the truth of the gospel

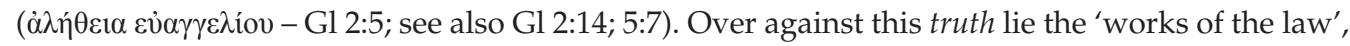
which legitimate and control things that belong to the elements of transient creation. The law might seem to be 'a good arrangement' to establish God's order, but it is no/ $t$ 'gospel' because it arises from and legitimises human conventions. Those who espouse this vision (akin to the so-called pillars in Jerusalem - referring to the apostles under the leadership of James, the brother

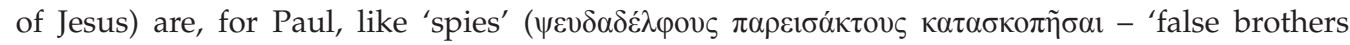

Note: This essay is dedicated to Ignatius (Natie) van Wyk, who became emeritus doctor in theology on 16 September 2018. I honour Natie van Wyk as one among the 'classic' theologians in South Africa. Meticulous research and reflection, always based on reading the original texts of his discussants - whether these documents had been written in Greek or Latin or Prussian German - form constituent aspects of this classic legacy. His criticism against the heresy of apartheid in church and society caused alienation for him and for me. However, he never silenced his prophetic calling that church cannot be church without being in ecumenical relationship with the other appearances of the universal church in its multifaceted denominations. For this, for his solidarity with my own theological and political disposition and for his consistency in doing theology, I honour Natie van Wyk in this article by collecting excerpts of my reflective perspectives on the primary texts of the pioneer in formative Christianity, namely the apostle Paul. 
brought in under false pretences'; cf. Newman 1971:135, signifying Gl 2:4), who mislead the followers of Jesus. As in a military-political plot, they rob the faithful of their freedom and turn them into slaves of the law (see Betz 1979:90, commenting on Polybius 1.18.3; 2.7.8; Diodorus Siculus 12.41.4; Plutarchus, Moralia 261B). However, Paul's 'gospel' is not vested in the conventions of people (even though they might be in positions of leadership). What Christ Jesus has revealed to him is the 'good news' that dying in participation with Jesus means the 'death' of the transitoriness of the 'old creation' and the resurrection implies the onset of the 'new creation'. This is what the proclamation [kerygma] of the 'Christ-event' is all about - not information about the gospel (cf. Keck 1988:35). The message in itself when proclaimed acquires power once it is trusted.

In his appealing to the non-Israelites Paul demands the renouncement from idolatry - meaning among other things the ultimate trust in human-made idols, which is to be compared with the trust in finiteness similarly to adhering to cultural ideals - and to serve the 'living and true God' (1 Th 1:9). He preached the same message in the synagogues where the audience consisted of believing Israelites and 'pious/god-fearing ones' - that is, Hellenists who felt themselves drawn to the Israelite faith (see Overman 1988:17-26) and who shared respect for the Hebrew Scriptures as God's revelation (Keck 1988:35). Speaking to them, he used words that differed from their traditional understanding of God and the Hebrew Scriptures. Christ's significance for humankind is universal, whereas the synagogue limited God's saving grace to the nation of Israel. He concurs with the prophets' message that God is the light of the nations (see Wright [1997] 1998:83). To Israel and the earliest Jesus-group in Jerusalem, this meant that the nations should come to Jerusalem (the centre of the cosmos and the church). Initially, Paul took no issue with this point of view (see Gl 2:7-10) but did so when they refused to interact with non-Israelites (Gl 2:1-14) by, for instance, sharing meals with them.

This new ethos is inaugurated because of the 'dying and rising' in participation with Christ Jesus. Thanks to God's resurrection of the crucified, the messianic era had already commenced (Den Heyer 1998:121). The cross and resurrection are undoubtedly the core of Paul's message and whenever he mentions the one (e.g. 'resurrection'), the other (e.g. 'cross') is assumed to be included (see inter alia, 1 Th 1:10; 1 Cor 2:2) (cf. Kümmel 1972:136).

Paul often describes this 'heart' of the gospel by means of a language pattern in a V-shape, for example, Romans 8:34. God first sends Jesus as Son. He descends into death (the lowest point) and is then raised to life and elevated to the right-hand side of the Father. The text also refers to Jesus, who, from an elevated position, intercedes for believers (see Hengel 1995:119-226). With regard to this 'God-Son' relationship of Jesus, Paul does not refer to a miraculous conception or to miraculous deeds of Jesus to be found in the Gospel narratives. He does not focus on information concerning Jesus (the so-called what of the historical Jesus - see Bultmann [1960] 1965:9) but rather on the redemptive result of the Jesus-events, namely death and resurrection.

Romans 3:24-26 explains the meaning and significance of this through 'sacrificial terminology' (see Dunn 1998:216223). Traditionally, it is sometimes understood that the purpose of the sacrifice was to pacify God, who is angry because of sin, by giving something to God ('propitiation'). Paul regards the death of Jesus differently, namely as expiation (German Sühnung) between God and humankind. This also implies that sin is expurgated, but in a different manner. The death of Jesus creates an entirely new dispensation. However, it seems that Paul perceived the death of Jesus apparently just as the first Jesus-group in Jerusalem did, in terms of the manner in which they understood sections such as Isaiah 53:4, 7, 8, 10 and 12 and the sacrificial temple rituals. It is within this context that Paul also refers to Jesus as 'our sacrificial lamb' (see 1 Cor 5:7-8). Yet he did not emphasise the blood spilt in the scene. With the image 'Jesus is our paschal lamb', he explained that Jesus is the 'holy one'. That is, he is the 'pure' one, the one who is 'unblemished' and therefore 'an image' of God. His death on the cross and his resurrection enables the recreation of believers (see Den Heyer [1998] 1998b:57-73). Paul also implies that Jesus is the 'mercy-seat' (Rm 3:23-25). The mercy-seat fulfilled an important function on the Day of Atonement (cf. Ex 25:16-20; Lv 16:14-16) (see Den Heyer [1998] 1998b:68-72). It indicated God's presence in the holiest of holies in the temple. By linking Jesus' death to the mercy-seat, Paul argues that God became a presence for all humankind on Golgotha and no longer in the temple (cf. Barrett [1957] 1967:77; Breytenbach 1986:698; Käsemann [1973] 1974:91).

\section{From Jesus to Paul}

In Paul's point of view, the heart of the gospel was the announcement of a historical happening, namely the crucifixion of Jesus, that was indissolubly connected to another 'event', namely the resurrection of Jesus from death by God. Strictly speaking, and from a modern empirical perspective, the latter does not qualify as history. From this point of view, Barth ([1924] 1933:139) and Keck (1988:39), among others, are of the opinion that the resurrection is a 'type of history' peculiar to those times (cf. Hitchcock 2013:93). Barth refers to the resurrection as Urgeschichte, whereas Bultmann does indeed call it 'history' but in the sense of objectified act of mythical speech. Bultmann ([1928] 1969a:83) explains his agreement and difference with Barth ([1924] 1933) as follows:

With this interpretation, Barth has supported his contention that [1 Cor 15:] vv. 3f. are not intended to be an historical account ... But it is plain that for Paul the resurrection of the dead was accepted also as an historical fact ... I [Bultmann] can understand the text only as an attempt to make the resurrection of Christ credible as an objective historical fact. And I see only that Paul is betrayed by his apologetic into contradicting himself. (p. 139, [author's own translation; emphasis by Bultmann]) 
It would, however, have been closer to Mediterranean premodern thought to talk about the resurrection in terms of the contemporaneous Mediterranean context of time and usage of motifs from the Hebrew Scriptures (cf. Van Aarde 2013a:35-42, 2013b:31-48). After the death of Jesus, certain traditions were doing the rounds (of which some probably originated with the first Jesus-group in Jerusalem) in connection with the acts of Jesus and his resurrection appearances. Evidently, Paul himself had not observed or heard the historical Jesus and he does not mention sources claiming that anyone else had visually seen the resurrection. Paul does refer to the traditions in connection with the appearances of Jesus (1 Cor 15:3-7), but he only refers to the appearance of Jesus to Peter and the disciples as a group, as it is mentioned in the canonical gospels (Lk 24:34; Ac 1:3; Jn $20: 19 ; 21: 14-15)$. He refers to the crucifixion but without any further detail. Neither does he mention the origin of the oral (or literary) tradition of the crucifixion. It is therefore not clear how much information Paul had about the historical Jesus. Expressions such as 'I received from the Lord ...' (1 Cor 11:23) or 'the Christ according to the flesh' (Rm 9:51) create the impression of a particular set of information, or, conversely, of the absence of such information. Taking into account that the earliest stratum of $\mathrm{Q}$ (consisting of Jesuslogia) (cf. Kloppenborg 2000:55-128) probably originated contemporaneously with Paul's letters, the question arises as to why Paul hardly refers to Jesus-logia. Could it be that he perhaps knew more but refrained from mentioning it because of the situational peculiarity of the ecclesial nature of his epistles (cf. Keck 1988:41)? Alternatively, did he have additional knowledge but simply lacked interest in the 'what' of the historical Jesus (a position held by Bultmann [1929] 1969b:220-246)?

According to Bultmann, the person and history of Jesus are of no consequence to the kerygmatic proclamation [Anspruch]. The quest for the historical Jesus behind the kerygma does not intend to evoke faith. It is, however, an existential given, and it is only with great endeavour that the gospel of Christ Jesus can be internalised and lived out in faith in our world of time and space. The 'cause of Jesus' [Sache Jesu] remains a skandalon [Anstoß], an 'offense' or even an obstacle [skandalon] to traditional religion (Smith 2011:229). Authentic life demands demythologising - that is, life communicated through the kerygma, which comes to us in myth (Intention des Mythos); in other words, by means of God-talk objectified through analogical language (cf. Dorrien 1997:188).

Dilthey's insights (cf. Dennison 2008:145) led Bultmann to the conviction that historical reconstruction, unlike what historicism held, did not consist of a version of the past that is without presupposition. An encounter with history pertains to a comprehending decisiveness. However, this is not a once-off choice and then over and done with. An existential decision [Entscheidung] evolves into another one and into yet another, repeatedly (cf. Martin 1976). That is how history reaches an end each time by yet another decision made. A decision with such an existential impact entails a choice for God's righteousness and against self-righteousness (cf. Thompson 2001:100) - a choice to be made repeatedly (cf. Batdorf 1994:188-189).

Because the results of historical research can never be regarded as complete, historical research cannot yield results proclaiming absolute validity. This is why Bultmann distinguishes between the concepts of historisch and geschichtlich (cf. Labron 2011:28). When history is expounded as a possibility for an understanding of the own existence, then authentic existence (i.e. to believe) is independent of a commitment to the world view of a given period. More specifically, belief is also independent of the ancient theist world view of three levels - heaven above and hell beneath the earth. Under historisch, Bultmann understands the usual historical factuality of an event, while geschichtlich refers to the existential consequence of such an event. In view of this distinction between historisch and geschichtlich, Bultmann has no problem whatsoever that the Bible is being subjected to the most severe and probing historical criticism (cf. inter alia Dinkler 1952:88). This is so because he holds the view that the matter that is at stake in the kerygma cannot be verified or falsified by historical textual inquiry. What the Bible says about human existence is not validated or invalidated by verification or falsification. Therefore, the matter really at stake is not the historische but the geschichtliche.

Bultmann did not yield to the philosophy of existentialism (see Ogden 1957; 1961). He relies on Paul's thinking. Therefore, an authentic understanding of the self (the pneumatic, i.e., the 'spiritual', over the sarkikos existence, i.e. the 'fleshly' transient human) cannot be realised by humankind itself. It happens through an act of mercy by God and comes from outside, namely by means of proclaiming the Word, the kerygma. This act of mercy happens in and through the historical human being, Jesus of Nazareth. Almost a century earlier Friedrich Schleiermacher (CG 2 [1830/31] 2003:\$10.1, KGA 1.13.1:81) refers to this 'basic fact' as the Grundtatsache, which constitutes the distinctiveness of Christianity. Vander Schel (2013:95) describes Schleiermacher's (CG 2 [1830] 1831; in KGA $1.13 .1 ; 93$ ) view that the peculiarity of the piety (religiosity) of Jesus-followers that distinguishes itself from other such ways of faith in that in it everything is related to the redemption accomplished through Jesus of Nazareth' (Schleiermacher [1830/1831] 2003:§10.1, KGA 1.13.1:81):

That Christianity traces its communal life back to Christ is a fact Schleiermacher regards as beyond dispute. The appearance of the Redeemer in history forms the 'basic fact' (Grundtatsache) distinguishing Christianity throughout. Distinctively Christian piety could simply not be possible 'outside of all historical connection with the impulse proceeding from Christ '(mit dem von Christo ausgegangen Impuls).

This insight is fully concurrent with Paul's thinking. For Paul, the 'First Adam' metaphorically denotes the 'human condition' (cf. Van Aarde 2018), that is, humanness 'in the condition of the sarx' (Cooper 1973:246). Grundmann and Stählin (1933:313) describe Paul's use of the Adam motif as 
reference to the Todesschicksal der Menschheit und der allgemeinen sündigen Zuständlichkeit (paraphrased in the following way: 'sin understood to be the universal condition of humankind destined to die'). The two

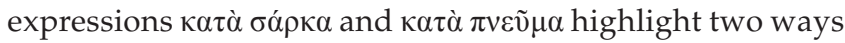
of existence according to two aeons: the perishable human existence and the sphere of divine existence (see Jewett 2007,103-106), or in terms of the way in which Schleiermacher sees Jesus' humanness ('incarnation') as the 'supernaturalbecoming-natural' [Naturwerden des Übernatürlichen] (see Vander Schel 2013, 11 n. 25). ${ }^{1}$ In Pauline Christology the

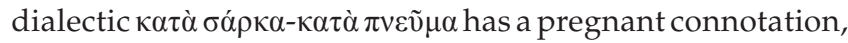
in that 'in Christ the divine sphere has invaded the human' (Schweitzer 1985):

In Rom. 1:3-4 Paul contrasts the sphere of sárx with that of heaven or pneuma. In this limited and provisional sphere Jesus is the Davidic Messiah, but the decisive thing comes in the sphere of the pneuma ... $[I] \mathrm{t}$ indicates sphere rather than origin ...The present aeon or cosmos may be equivalent to sárx (cf. 1 Cor. 2:6), but the real antithesis is between God and humanity ... [Yet] God's promise is the opposite of sárx (Rom. 9:8). In Christ the divine sphere has invaded the human. (p. 1004)

For Paul, true significance is to be found in what God brought about by allowing the crucifixion and resurrection and not by what Jesus said and did in God's name. However, this does not imply that Paul misrepresented Jesus' vision. The shame of death by crucifixion was seen by Paul as the 'condensation' of the entire insignificant life of Jesus, beginning with his being born out of an unimportant woman (cf. Gl 4:4) and ending in the humiliation of his death on the cross (cf. Phlp 2:8). Crossan (1994:10) uses the expression 'history remembered' to refer to Paul's linking of his emphasis on the substance of the significance of the 'Jesus of faith' to the 'Jesus of history'. The latter is the Jesus of 'flesh and blood' (cf. 1 Cor 15:50). Bultmann views the expression 'Christ according to the flesh' as a description of Jesus' Unscheinbarkeit (i.e. 'Christ in his plainness' - Bultmann ([1976] 1985:155).

Although a discontinuity in content between the words and deeds of Jesus and the Pauline kerygma might be discernible, an apposite relationship between the two exists. The discontinuity in content is especially linked to Paul's message regarding expiation emanating from the death and resurrection of Jesus. Paul reasoned that God allowed Jesus to be killed so that humankind could be saved from sin. He also declared that he proclaimed no other message than that of the 'crucified Christ' (1 Cor 1:23). That is his kerygma. Jesus did not see his death in a similar way (see Van Aarde 2017: p. 4 of 10). The gist of Paul's kerygma, however, does have a contextual link with what Jesus proclaimed. Paul's kerygma is unconventional in all respects. For him, Jesus' death terminates all of humankind's reliance on finiteness such as conventions. This trust in tradition - either cultural or religious - is, in his view, the 'sin' from which God delivers humankind. The message of Jesus was also unconventional. It was subversive wisdom intending the same as Paul's kerygma: conventions do not bring you into the right relationship with God. God is directly and immediately present in all of humankind.

The Pauline proposition that authentic life is only possible based on faith and not on adherence to Mosaic laws is an apposite résumé of the subversive wisdom of Jesus. Mosaic laws legitimised and regulated the people's trust in conventions. Paul's proposition concerning 'faith alone' is based on his conviction that the death of Jesus implies metaphorically the termination of the law and that the resurrection is the beginning of the 'new' human being (2 Cor 5:17), liberated from the burden of the law. Although Jesus did not view his death like this, his words and deeds were tantamount to the same thing. Jüngel (1962:266) defines Romans 1:17 as a compact summary of the message of Jesus. In another publication on Paul's outlook, I formulated the dialectic continuity-discontinuity between Jesus and Paul as follows:

With retrospection, Paul interpreted Jesus' death as a deed of redemption; a deed 'for us' (pro nobis). By inference, one can say Jesus' understanding of his followers' deaths is compatible with Paul's understanding of the death of Jesus' followers. The life of Jesus was condensed in his death. Mark's understanding of Jesus' directive that his followers take up their cross and die in order to gain life (Mk 8:34-37) is the core of the message that God creates new life when one dies to this aiōn (Rom 6:2-11). According to Jesus, authentic life was not to be found in pleasing people, but in doing God's will (Mk 8:33). It cannot be found in conventions, culture, ethnicity or anything from this world. (Van Aarde 2017: p. 4 of 10)

Since Albrecht Ritschl ([1882] [1972] 1999:154-171) it has been generally accepted in Jesus studies that Jesus of Nazareth, ethnically an Israelite, crossed a variety of boundaries without being 'un-Jewish'. This is one of the clearest aspects in Paul's emphasis of the 'new human being' who does not need to adhere to 'Mosaic laws', which, among other things, define the 'inside group' over against the 'outside group'. In the time of formative Christianity, this hetero-normative thinking had severe consequences. It implies the 'markers' in identity formation, the realisation of authentic personhood and the obligations of cultural observance of diet and calendar in terms of 'purity' or 'pollution' - that is, who would be conventionally be regarded socially and religiously acceptable or disreputable. In other words, the Pauline expression 'by faith alone' is not an abstract truism. It has concrete historical roots (see Jüngel [1990] 1995:82-119) in Jesus' crossing of gender, ethnic and cultural boundaries. According to Paul, finiteness and death are the realities within which humankind lives - and this encompasses all manner of trauma.

Finiteness is actually the essence of existence. The yearning for redemption is the search for infinity, a life that is not determined by what is human or part of creation, but by the Spirit of God. Such a life is tantamount to a meaningful and meaning-giving existence before God (that implies service to God and to one another) in the midst of trauma and in spite of death. Paul cries out (Rm 7:24-25): 
What a wretched man I am! Who will rescue me from this body that is subject to death? Thanks be to God, who delivers me through Jesus Christ our Lord!²

Believers are destined to 'conform to the image of the Son of God' (cf. Rm 12:2). Paul says: 'In the same way, count yourselves dead to sin but alive to God in Christ Jesus' (Rm 6:11) and elsewhere: 'In your relationships with one another, have the same mind-set as Christ Jesus' (Phlp 2:5). To Paul, the kerygma of Jesus Christ's death, resurrection, being raised up and seated on the right hand of God, together with his intercession for the faithful, are all expressions of his thanks to God. This is not cognitive language but liturgical praise. To subject it to cognitive examination and neglect to see the spiritual dimension is to miss the purpose of Paul's kerygma. Paul gives thanks to God in a confessional thanksgiving or praise because God has delivered us from our mortal existence.

In order for us to understand Paul's message of redemption, it is necessary to see that all of humanity is lost and destined for death (see Kümmel 1972:159-161). God did indeed create this world but, through Adam's sin, death came into this world and God subjected creation to mortality ( $\operatorname{Rm} 1: 20 ; 5: 12$; $8: 20)$. Thus, this world is subject to the power of worldly elements, spiritual powers and to the devil as god of this aion [the immanent dispensation] (Gl 4:3; 1 Cor 2:6, 8; 2 Cor 4:4; cf. $\mathrm{Col}$ 2:20). Humankind is addicted to these powers. Paul also refers to people in their lostness as 'slaves' who are bound to the restrictions of the cosmos ( $\mathrm{Rm} 3: 19$ ). These people are far removed from God and refuse to recognise God, although they know about God ( $\operatorname{Rm} 1: 20)$. They glory in their own might (whereas they are weak in God's eyes) (1 Cor 1:27-29). They oppose God. Therefore, they are without exculpation and are alienated from their godly destination ( $\operatorname{Rm} 1: 20 ; 3: 23)$. However, all humans remain God's creation and are answerable to God.

\section{The answer to the Gospel as part of an ellipse}

In Paul's gospel, the message of Christ forms an ellipse between the kerygma and its respondents (cf. Keck 1988:49-55). When Paul talks about God or Christ, it deals with his audience's authentic life. The gospel is not a series of statements about God or Christ that might merely be accepted as cognitively true without being life-changing. Christology therefore implies soteriology, and vice versa. The gospel is 'good news' only when it is believed. Paul expresses this in various ways. Each expression focuses on a particular facet of human mortality and how one can be liberated from it. Redemption presupposes an earlier alienation from, or hostility towards, God. Redemption is the 'buying back' of the sinner, and it is comparable to redeeming an article at a

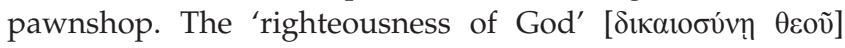
emanates from this act of 'buying back'. This results in

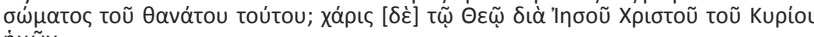
ท่ $\mu \tilde{\omega} v$. putting the human being, as part of creation, into the correct relationship with God. However, in the vocabulary of Paul, the terms 'forgiveness' and 'rebirth' are absent. His kerygma (namely that Christ died for our sins and was resurrected by God to become Lord) was not a matter commonly understood by all. Faith brings this insight. The gospel is good news only when it is believed. When it is detached from faith, Paul's preaching brings no salvation.

For Paul, faith is engagement with the kerygma and not a kind of loyalty to inherited religious customs. It is a personal decision and commitment to believe what is proclaimed. To Paul, it is not sufficient that one believes. It is of importance what one believes. The what is the existential meaning of the cross and the resurrection, whereby the believer becomes involved by dying to the self and becoming a new person. Faith is an answer, an obedient involvement (cf. Rm 10:17) not a conclusion based on what one thinks is the correct way to believe. Humankind cannot save itself. This can only be brought about by a 'Word' that brings an alternative to selfinterest and that calls for an answer to God's offer of redemption. The appropriate answer to hearing the gospel is obedience (1 Th 1:8; Rm 1:5; 16:19), after the example set by Jesus. However, this is not compliance with a command but response to a claim made by the gospel. It does not presuppose mere intellectual agreement but an answer that reveals something about one's spirituality and also indicates that some action is to take place. Undivided loyalty to God is genuine only when it consists of loyalty towards something outside of 'the self' - towards God, the gospel and the Christ proclaimed by the gospel. Otherwise, it would, in a manner of speaking, have to be faith in faith; trust in the power of trust. This would imply that a person would be compelled to grow in faith, for whoever believes the most shall be saved. This clearly is not what Paul had in mind. Followers of Jesus are not 'super-believers'. They are committed to the message of the gospel, and faith places them in the correct relationship with God despite race, nationality, gender, sexual orientation, age or status. Paul naturally was aware of these distinctions, but they do not determine the relationship with God (Gl 3:28). Such is God. Likewise, to Paul, God is neither an Israelite nor a non-Israelite God. He also is not a denominational God. God is the one and only God.

However, it is a condemnation that the words of Friedrich Nietzsche (1844-1900), 'I might believe in the Redeemer if his followers looked more redeemed' (Sherry 2003:38) remain a truism. According to Nietzsche, Christendom represents the lowest form of god-view in the descending order of deities: 'If the world has indeed been saved or redeemed, why is this not more apparent' (see Fink 2003:121-124). Nietzsche distinguishes between the 'evangelical Jesus' and the 'church-founding Paul' (see Fink 2003:122). According to him, Jesus is innocent. Paul is the culprit who transformed the conciliatory Jesus into a system bent on conforming to gratifying human desires and structures (Fink 2003:123). In the light of Nietzsche's accusation against Christendom and against Paul in particular, the question remains whether Paul 
wished to please with his proclamation of reconciliation. Paul's message about the 'crucified' did not impress Nietzsche. The Crucified is for him a 'symbol of great suffering renouncing the concrete world' and 'represents a morality which is foreign to life and a utopian religious and metaphysical ideal' (in Fink 2003:166).

Friedrich Schleiermacher (1768-1834) would disagree. According to him, the 'ministry of reconciliation' (cf. 2 Cor 5:20-21) constitutes the 'well-being' of the church (Schleiermacher [1830] 1960:§ 127.2). In 1 Corinthians 1:17 Paul writes: 'For Christ did not send me to baptise, but to preach the gospel - not with wisdom and eloquence, lest the cross of Christ be emptied of its power'. In 1 Thessalonians 2:4 he maintains that he passed the divine test because God had entrusted the gospel to his heart and he has no urge to

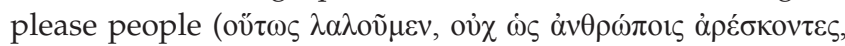

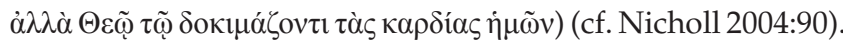
Earl Richard (1995) puts it like this:

The theme of 'pleasing mortals' especially through flattery and deceitful behavior was common in both Greek and Jewish literature but that of 'pleasing God' as a motive for missionary rhetoric and behaviour is due to Pauline creativity. (p. 80)

For this reason Paul emphasises that in the acts of redemption there is nothing the believer has any cause to boast about $(\mathrm{Rm} 3: 27)$. It is God who is active here and God does it free

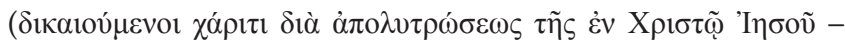
$\mathrm{Rm} 3: 24)$. Therefore, no glory is because of humankind.

This, however, does not imply absence of human response. Lambrecht (1999:97), when talking about the expression 'new creation', says, " New things" come into existence only if there is human acceptance. The replacement of the old does not occur automatically'. Undivided loyalty, therefore, is the answer to redemption through Christ Jesus. Trust (i.e. faith) is, after all, an affective occurrence. It is the response of a human in the totality of all her or his human dimensions: knowledge, emotions and conduct. Yet Paul's message of reconciliation did not intend to take the human being as object embedded in the cultural context of conventions and make of it a better person. Neither does it intend to establish new conventions. If this had been the case, then we would, just as Paul pointed out to the Galatians (3:3), be 'foolish', because we, who started out with the Spirit of God, would then have ended up with the inauthenticity of fallible humans once again. Although faith as 'undivided loyalty' certainly presupposes a dynamic ethical dimension, faithfulness does not presuppose a 'better' life than that of the unbeliever, but a life radically different from a life without God.

\section{Acknowledgements Competing interests}

The author declares that he has no financial or personal relationships which may have inappropriately influenced him in writing this article.

\section{References}

Agamben, G., 2005, The time that remains: A commentary on the letter to the Romans, transl. P. Dailey, Stanford University Press, Stanford, CA.

Barrett, C.K., [1957] 1967, A commentary on the epistle to the Romans, reprinted, Adam \& Charles Black, London (BNTC).

Barth, K., [1924] 1933, The resurrection of the dead, transl. H.J. Stenning, SCM Press, London.

Batdorf, I.W., 1994, Interpreting Jesus since Bultmann: Selected paradigms and their hermeneutic matrix, SBL Seminar Papers, Scholars Press, CA, pp. 187-215.

Betz, H.D., 1979, Galatians: A commentary on Paul's letter to the churches in Galatia, Fortress, Philadelphia, PA (Hermeneia).

Blumenfeld, B., 2001, The political Paul: Justice, democracy, and kingship in a Hellenistic framework, Sheffield Academic Press, Sheffield.

Breytenbach, C., 1986, 'Probleme rondom die interpretasie van die "versoeningsuitsprake" by Paulus', HTS Theological Studies 42(4), 696-704. https://doi.org/10.4102/hts.v42i4.2206

Breytenbach, C., 1989, Versöhnung: Eine Studie zur paulinischen Soteriologie, Neukirchener Verlag, Neukrichen-Vluyn, Germany (WMANT 60).

Bultmann, R., [1928] 1969a, 'Karl Barth: The resurrection of the dead', in R. Bultmann (ed.), Faith and understanding, vol. I, pp. 66-94, edited with an introduction by R.W. Funk and transl. L.P. Smith, SCM Press, London.

Bultmann, R. [1929] 1969b, 'The significance of the historical Jesus for the theology of Paul', in R. Bultmann (ed.), Faith and understanding, vol. I, pp. 220-246, edited with an introduction by R.W. Funk and transl. L.P. Smith, SCM Press, London.

Bultmann, R., [1960] 1965, Das Verhältnis der urchristlichenChristusbotschaftzum historischen Jesus, 4th edn., Carl Winter, Universitätsverlag, Heidelberg (SHAW 3).

Bultmann, R., [1976] 1985, The second letter to the corinthians, transl. R.A. Harrisville, Augsburg, Minneapolis, MN.

Constantineanu, C., 2006, 'The social significance of reconciliation in Paul's theology with particular reference to the Romanian context', Doctoral dissertation, School of Theology and Religious Studies and The Centre for Mission Studies, University of Theology and Religious Studies and The Centre for Mission Studies, University of
Leeds, viewed 30 August 2018, from https://core.ac.uk/download/pdf/43650.pdf

Cooper, E.J., 1973, 'Sarx and sin in Pauline theology,' Laval théologique et philosophique 29(3), 243-255.

Crossan, J.D., 1994, 'The historical Jesus in earliest Christianity', in J. Carlson \& R.A. Ludwig (eds.), Jesus and faith: A conversation on the work of John Dominic Crossan, pp. 1-21, Orbis Books, Maryknoll, NY.

Den Heyer, C.J., 1998a, Paulus: Man van twee werelden, Meinema, Zoetermeer.

Den Heyer, C.J., [1998] 1998b, Verzoening: Bijbelse notities bij een omstreden thema, Zevende, uitgebreidedruk, Kok, Kampen.

Dennison, W.D., 2008, The young Bultmann: Context for his understanding of God, 1884-1925, Peter Lang, New York.

Dinkler, E., 1952, 'Existentialist interpretation of the New Testament', The Journal of Religion 32(2), 87-96. https://doi.org/10.1086/484260

Dorrien, G.J., 1997, The word as true myth: Interpreting modern theology, Westminster John Knox Press, Louisville, KY.

Dunn, J.D.G., 1998, The theology of Paul the apostle, Eerdmans, Grand Rapids, MI.

Elliott, N., 2005, Liberating Paul: The justice of God and the politics of the apostle, Fortress, Minneapolis, MN.

Fink, E., 2003, Nietzsche's philosophy, transl. G. Richter, Continuum, London.

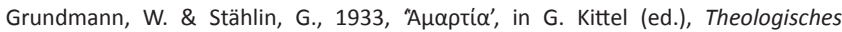
Wörterbuch Zum Neuen Testament, vol. 1, pp. 267-320, Kohlhammer, Stuttgart.

Hengel, M., 1995, 'Sit at my right hand!', in M. Hengel (ed.), Studies in early Christology, pp. 119-226, T \& T Clark, Edinburgh.

Hitchcock, N., 2013, Karl Barth and the resurrection of the flesh: The loss of the body in participatory eschatology, Pickwick Publications, Eugene, OR.

Jewett, R., 2007, Romans: A commentary, Fortress, Minneapolis, MN (Hermeneia).

Jüngel, E., 1962, Paulus und Jesus, J. C. B. Mohr, Tübingen.

Jüngel, E. [1990] 1995, 'The dogmatic significance of the question of the historical Jesus', in E. Jüngel (ed.), Theological essays, vol. II, pp. 82-119, edited with an introduction by J.B. Webster and transl. A. Neufeldt-Fast and J.B. Webster, T\&T Clark, Edinburgh.

Käsemann, E., [1973] 1974, An die Römer, 3rd rev. edn., Mohr, Tübingen (HNT 8a).

Keck, L.E. [1979] 1988, Paul and his letters, 2nd edn., revised and enlarged, Fortress, Philadelphia, PA (Proclamation Commentaries).

Kloppenborg, J.S., 2000, Excavating Q: The history and setting of the Sayings Gospel, Fortress, Minneapolis, MN.

Kümmel, W.G., 1972, Theologie des Neuen Testaments nach seiner Hauptzeugen Jesus, Paulus, Johannes, 2nd expanded edn., Vandenhoeck \& Ruprecht, Göttingen, (Grundrisse zumNeuen Testament 3).

Labron, T., 2011, Bultmann unlocked, T\&T Clark International, London (A Continuum imprint).

Lambrecht, J., 1999, Second Corinthians, Liturgical Press, Collegeville, MN (Sacra Pagina Series 8).

Martin, G.M., 1976, Vom Unglauben zum Glauben: ZurTheologie der Entscheidung bei Rudolf Bultmann, Theologischer Verlag, Zürich (TheologischeStudien 118). 
Newman, B.M., 1971, A concise Greek-English dictionary of the New Testament, UBS, London.

Nicholl, C.R., 2004, From hope to despair in Thessalonica: Situating 1 and 2 Thessalonians, Cambridge University Press, Cambridge.

Ogden, S.M., 1957, 'Bultmann's project of demythologization and the problem of theology and philosophy', Journal of Religion 37(2), 156-173. https://doi.org/ $10.1086 / 484941$

Ogden, S.M., 1961, Christ without myth: A study based on the theology of Rudolf Bultmann, Harper \& Brothers, New York.

Overman, J.A., 1988, 'The God-fearers: Some neglected features', Journal for the Study of the New Testament 32, 17-26.

Richard, E.J., 1995, First and second Thessalonians, Liturgical Press, Collegeville, MN (Sacra Pagina Series 11).

Ritschl, A. [1882] [1972] 1999, 'Instruction in the Christian religion', in G.W. Dawes (ed.), reprinted from Three essays, copyright Philip Hefner, and republished in The historical Jesus quest: Landmarks in the search for the Jesus of history, pp. 154-171, Westminster John Knox Press, Louisville, KY. [Original German: Ritschl, A 1882, Die christliche Lehre von der Rechtfertigung und Versöhnung. Bonn: Marcus Verlag.]

Schleiermacher, F.D.E., [1830/1] [1960] 2003, Der christliche Glaube nach den Grundsätzen der evangelische Kirche im Zusammenhange dargestellt [CG2], 2nd edn., R. Schäfer (ed.), Kritische-Gesamtausgabe [KGA], Walter de Gruyter, New York.

Schweitzer, E., [1964] 1985, 'Sárx (flesh, body), sarkikós (fleshly, earthly), sárkinos (fleshly, fleshy): The Greek World', in G.F. Bromiley (ed.), Theological dictionary of the New Testament: Abridged in one volume, pp. 1001-1007, Eerdmans, Grand Rapids, MI.
Sherry, P., 2003, Images of redemption: Art, literature and salvation, T \& T Clark, London.

Smith, J.H., 2011, Dialogues between faith and reason: The death and return of God in modern German thought, Cornell University Press, Ithaca, NY.

Thompson, M.M., 2001, The God of the Gospel of John, Eerdmans, Grand Rapids, MI.

Van Aarde, A.G., 2013a, 'Caught in the snare of she'ol, but dew gives life to dust', in J.H. Ellens (ed.), Heaven, hell, and the afterlife: Eternity in Judaism, Christianity, and Islam, Volume 1: End time and afterlife in Judaism, pp. 35-42, Praeger, Santa Babara, CA (Psychology, Religion, and Spirituality).

Van Aarde, A.G., 2013b, 'The tomb cult of the early Jesus-followers', in J.H. Ellens (ed.), Heaven, hell, and the afterlife: Eternity in Judaism, Christianity, and Islam, Volume Two: End time and afterlife in Christianity, pp. 31-48, Praeger, Santa Barbara, CA (Psychology, Religion, and Spirituality).

Van Aarde, A.G., 2017, "'By faith alone" (undivided loyalty) in light of change agency theory: Jesus, Paul and the Jesus-group in Colossae', HTS Theological Studies 73(3), a4355. https://doi.org/10.4102/hts.v73i3.4355

Van Aarde, A.G., 2018, 'Reading the Christ hymn in Philippians in light of Paul's letter to the Romans', Neotestamentica. (Forthcoming)

Vander Schel, K.M., 2013, Embedded grace: Christ, history, and the reign of God in Schleiermacher's dogmatics, Fortress, Minneapolis, MN (Emerging Scholars).

Ward, G., 2012, 'Theology and postmodernism: Is it all over?', Journal of the American Academy of Religion 80(2), 466-484. https://doi.org/10.1093/jaarel//fr099

Wright, N.T., [1997] 1998, Paulus van Tarsus: Een kennismaking met zijn theologie, vertaaldeur M Rotman, Meinema, Zoetermeer. 